\title{
Human listerial meningitis
}

\author{
I. M. LIBRACH AND R. K. SETH \\ From Chadwell Heath Hospital, Romford, Essex
}

SYNOPSIS A case of Listerial meningitis is described in a man of 60 years. The aetiology of listeriosis is discussed.

Human listeriosis is widespread throughout the world (W.H.O. Report, 1959), some 400 cases having been reported so far (Seeliger, 1958), but its existence has been neglected in Great Britain. Only some eight cases have been recorded (Lane, Watling, and Marshall, 1959), the majority in infants. Seeliger thinks that there has not been any real increased incidence but considers that there has been a greater awareness of the condition recently.

\section{CASE REPORT}

F.E.L., a married man, aged 60 years, worked as a plant attendant at the Northern Sewage Outfall Works, Barking. He was admitted on 15 September 1959 with severe headache and vomiting for three days. He had had no major illnesses.

On examination, his temperature was $100^{\circ} \mathrm{F}$., pulse 88, respiration 18 . He was irritable and delirious. Neck stiffness and Kernig's sign were present. Blood pressure was $130 / 70 \mathrm{~mm}$. Hg. An aortic systolic murmur was heard. The glans penis was red and swollen and discharging from the preputial space. There were no other signs.

INVESTIGATIONS On admission the cerebrospinal fluid was turbid containing 800 cells per c.mm. $(80 \%$ polymorphonuclears), protein $200 \mathrm{mg}$. \%, sugar $20 \mathrm{mg}$. \%, and chloride $660 \mathrm{mg}$. \%.

When the examination was repeated on 26 August, the cerebrospinal fluid was slightly turbid, containing 225 cells per c.mm. (90\% lymphocytes), protein $60 \mathrm{mg}$. \%, and chlorides $660 \mathrm{mg}$. \%. No growth was obtained on culture.

Blood culture showed Gram-positive bacilli identified as Listeria monocytogenes type 4B. Haemoglobin was $102 \%(14.9$ g. $\%)$, white cells 12,700 per c.mm. $(84 \%$ polymorphonuclears).

A swab taken from the preputial space showed no growth and urine was sterile on culture.

An E.C.G. was normal.

Paper strip electrophoresis gave total protein, $8.5 \mathrm{~g} . \%$ (albumin $4.75 \mathrm{~g} . \%, a_{1}$ globulin $0.35 \mathrm{~g} . \%, a_{2}$ globulin 0.85 g. $\%, \beta$ globulin 1.05 g. $\%, \gamma$ globulin 1.5 g. $\%$ ).

Received for publication 19 May 1960.
The pattern was abnormal and the $a_{2}$ and $\beta$ globulin fractions abnormal.

Detailed bacterial studies were performed on blood and cerebrospinal fluid and both yielded a growth of small $(1 \mathrm{~mm}$. overnight) greyish low-convex colonies, with an entire edge, surrounded by a zone of slight $\beta$ haemolysis. Morphologically this was a Gram-positive bacillus (approximately $2.5 \times 0.5 \mu$ ) with rounded ends. Some of the organisms presented in pairs and a few in long chains. The organism grew aerobically at $37^{\circ} \mathrm{C}$. and at room temperature. The $37^{\circ} \mathrm{C}$. cultures in liquid media showed no motility, but a culture in peptonewater incubated overnight at room temperature was sluggishly motile, and, in peptone-water/maltose it showed a moderately active 'tumbling' motility. On solid media the organism behaved as follows:

\begin{tabular}{lll} 
Media & Room Temperature & $37^{\circ} \mathrm{C}$. \\
\hline $\begin{array}{l}\text { Nutrient agar, 18 hr. } \\
\text { Blood-agar, 18 hr. }\end{array}$ & $\begin{array}{l}\text { Slight growth } \\
\text { Scanty growth with } \\
\text { slight zone of } \beta \\
\text { haemolysis }\end{array}$ & $\begin{array}{l}\text { Moderate growth } \\
\text { Moderate growth } \\
\text { with distinct zone } \\
\text { of } \beta \text { haemolysis } \\
\text { Growth just visible } \\
\text { Visible growth }\end{array}$ \\
$\begin{array}{l}\text { MacConkey's agar, 18 hr. } \\
\text { MacConkey's agar, 72 hr. } \\
\text { Gelatin stab, 18 hr. }\end{array}$ & $\begin{array}{l}\text { Visible growth } \\
\text { Growth along line } \\
\text { of stab }\end{array}$ & - \\
$\begin{array}{l}\text { Gelatin stab, 1 week } \\
\text { Loeffler's serum, 18 hr. } \\
\text { Goeffler's serum, 1 week }\end{array}$ & $\begin{array}{l}\text { Growth } \\
\text { No liquefaction }\end{array}$ & $\begin{array}{l}\text { Growth } \\
\text { No liquefaction }\end{array}$ \\
Indole production, 1 week & - & -
\end{tabular}

Serum-broth cultures incubated for eight or 10 hours at $37^{\circ} \mathrm{C}$. produced a soluble haemolysin active against horse red cells. Its fermentative characteristics at both $37^{\circ} \mathrm{C}$. and room temperature were:

\begin{tabular}{|c|c|c|c|c|c|c|}
\hline & Glucose & Lactose & Dulcite & Sucrose & Mannite & Maltose \\
\hline $18 \mathrm{hr}$. & - & - & - & - & - & - \\
\hline $36 \mathrm{hr}$. & $\begin{array}{l}\text { Acid, no } \\
\text { gas }\end{array}$ & - & - & - & - & - \\
\hline $48 \mathrm{hr}$. & $\begin{array}{l}\text { Acid, no } \\
\text { gas }\end{array}$ & $\begin{array}{l}\text { Acid, no } \\
\text { gas }\end{array}$ & - & - & - & - \\
\hline 1 week & $\begin{array}{l}\text { Acid, no } \\
\text { gas }\end{array}$ & $\begin{array}{l}\text { Acid, no } \\
\text { gas }\end{array}$ & - & $\begin{array}{l}\text { Acid, no } \\
\text { gas }\end{array}$ & - & - \\
\hline
\end{tabular}

SENSITIVITY TO ANTIMICROBIAL AGENTS In vitro, the organism was highly sensitive to sulphafurazole, penicillin, streptomycin, erythromycin, chloramphenicol, tetracycline, neomycin, and oleandomycin. The organism 
was presumed to be Listeria monocytogenes and the N.C.T.C. 7974 strain was obtained for comparative agglutination tests, which were placed in the $37^{\circ} \mathrm{C}$. water-bath for 18 hours and then stored overnight at about $10^{\circ} \mathrm{C}$. before final readings were made. Formolized and alcoholized suspensions of the patient's organism and of the N.C.T.C. strain gave the following titres (expressed as reciprocals) in $\mathrm{H}$ and $\mathrm{O}$ agglutination tests respectively.

\begin{tabular}{lcc} 
& $\begin{array}{c}\text { Patient's } \\
\text { Organism }\end{array}$ & $\begin{array}{l}\text { N.C.T.C. } \\
7974\end{array}$ \\
\hline Patient's serum and H suspension & 160 & 40 \\
Patient's serum and O suspension & 80 & 80 \\
Normal serum and H suspension & 10 & 20 \\
Normal serum and O suspension & Less than 10 & 10
\end{tabular}

The strain was tested by Dr. Edmunds (Edmunds, Nicholson, and Douglas, 1957) against absorbed factor specific $L$. monocytogenes sera. There were positive reactions with $\mathrm{H}$ factor $\mathrm{A}\left(25^{\circ} \mathrm{C}\right.$. cultures giving good $\mathrm{H}$ agglutination) and against $\mathrm{O}$ factor $\mathrm{V}$, but not against $\mathrm{H}$ factor $\mathrm{D}$ and $\mathrm{O}$ factors $\mathrm{I}$ and IV.

TREATMENT On admission, benzyl-penicillin, 1 mega unit six hourly, was given and continued for two weeks, totalling 56,000,000 units, and, sulphadimidine, $4 \mathrm{~g}$. followed by $2 \mathrm{~g}$. six hourly for 24 hours; on the following day chloramphenicol, 2 g. daily, and streptomycin sulphate were started and $2 \mathrm{~g}$. given daily for nine days, a total of each of $19 \mathrm{~g}$; then intravenous dextrose $(4.82 \%)$ with saline $(0 \cdot 18 \%)$, each $500 \mathrm{ml}$. containing $100 \mathrm{mg}$. hydrocortisone, were given to a total of $2,400 \mathrm{ml}$.; and oral prednisone, $10 \mathrm{mg}$. six hourly, gradually tailing off to a total of $140 \mathrm{mg}$.

PROGRess During the first 24 hours he had to be catheterized twice but the temperature became normal within this time. Within three days he was well and was discharged symptomless on 12 September. Three months later he was still well and back at work not as a sewage worker but in the power house.

\section{DISCUSSION}

A purulent meningitis of uncertain origin was first diagnosed. As in other cases, the organism was sensitive in vitro to many agents. In view of the number of drugs used, no conclusion as to their individual efficacy was possible. Seeliger, however, considers tetracycline to be the drug of choice. Steroids were given early because of their reputed anti-toxaemic action and because some petechiae were seen which suggested early adrenal insufficiency.

The source of infection remains obscure in human beings and in animals. In both, isolated single cases are not uncommon. Though the morbidity is low, mortality in affected animals is high. Like human beings, young animals are more susceptible than adults, the disease being more rapid in them. In human beings, however, the outlook is said to be worse in those over 60 years of age.
In poultry a lowering of flock resistance, e.g., b甲 parasites or salmonellosis, seems necessary befor Listeria can cause high losses. In cattle the disease is commoner when fresh green food is scarce. The difficulty of reproducing the disease artificiall suggests that unknown factors are present. Brennaas and Brochmann (1959) report a fatal case in a ma® with lymphosarcoma. Jessen (1958) thinks th\&्छ association with malignant disease is common in human listeriosis. There are several reports of

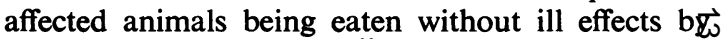
stockmen and farmers. Ödegaard, Grelland, anฐ Henriksen (1952) suggest that a farmer acquired fatal infection from healthy ovine carriers, but in $\overrightarrow{\overrightarrow{\vec{A}}}$ fection might equally well have been from farmer to sheep.

The positive blood culture in this case suggest $\xi^{\mathrm{N}}$ entry through the skin, possibly of the hands or feet when the patient took off his boots; a number of cases have been reported in shoe repairers. Biglan (1950) isolated the organism from canaries an $\bar{\Phi}$ chickens. Our patient kept two budgerigars but. examination of their droppings was negative.

Septicaemia with enlarged lymph glands occasionally occurs in this disease and may be confuse $\$$ with infectious mononucleosis (Girard and Murray 1951). In the present instance there was a polymorp leucocytosis. Many authors hold that the incubation period is exceptionally long for bacterial disease, bu this is surely difficult to substantiate in the absence of any known source of infection. Others describe $\$$ chronic course of weeks or months, unlike the one month's duration of the present case (Seeliger an Cherry, 1957). Meningeal involvement is the coma mon presenting form in adults, and it seems likely that it is secondary to a blood stream infection as io this patient.

Listeria has been recovered from the urethra of some adult males, but despite the presence of active inflammation, no organisms were isolated from this patient's urine or prepuce. Wedemeyer and Seelige? (1959) found an increased serum antibody titre i the mothers of five neonatal cases. A titre of 1 iff 320 was regarded as significant. The relevant titres in this case were $O 1$ in 80 and $H 1$ in 160, bu it should be remembered that the presence of $\mathrm{gN}^{\mathrm{N}}$ raised titre alone is insufficient for diagnosis? Wedemeyer and Seeliger (1959) also stress that the maternal titre is not increased in all proven neonata infections, overt disease being rare in mothers; this seems to weaken the theory of venereal spread some times put forward.

All reports agree that in neonates liver necrosis if a prominent feature unlike the picture in adulo meningitis. Meconium is said to swarm wite organisms but Wedemeyer and Seeliger (1959) dise 
agree. They stress pre-culture of meconium at $4^{\circ} \mathrm{C}$. for six weeks (Gray's method), a positive culture having been obtained in one of their cases after five weeks. These authors also state that the organism has been isolated from the placenta, cervix, and vagina both in human beings and animals. Winn, Cherry, and King (1958) stress that questioning the mother after abortion or premature birth frequently reveals some preceding influenzal-like symptoms.

The occurrence of conjunctivitis in laboratory workers may be of some importance. Although the source of infection has been undetermined, rubbing the eyes with an infected hand seems an obvious route.

Serum electrophoresis was abnormal in the present case, the $\alpha_{2}$ and $\beta$ globulin fractions being increased. Whether these fractions carry antibody or are related to the increased titres described previously is conjectural. According to Edmunds (personal communication), serological typing is not of much value epidemiologically. Most of the recorded cases in this country are type 2 or $4 \mathrm{~b}$ as in this instance, but differentiation of the five subtypes of type 4 is difficult.

In conclusion, Jessen (1958) optimistically thinks that the mortality from this disease, especially meningitis, has been significantly reduced by antibiotics, but this surely remains to be seen.
It is a pleasure to thank Mr. L. Whittaker for his perspicacity in isolating the organism, and Dr. T. F. Elias-Jones (group bacteriologist) for performing the extensive range of confirmatory tests and for permission to use the laboratory findings. Thanks are also due to Dr. P. N. Edmunds, formerly of Edinburgh, for serotyping the organism, and to Dr. R. W. Tannahill for his permission to publish this case and for his encouragement. We are also grateful to Dr. W. B. Cherry, of the Public Health Service, Georgia, U.S.A. for his help with the references.

\section{REFERENCES}

Bigland, C. H. (1950). Canad. J. comp. Med., 14, 319.

Brennaas, O., and Brochmann, A. (1959). J. Oslo Cy Hosp., 9, 219.

Edmunds, P. N., Nicholson, D. N., and Douglas, D. M. (1957). Brit. med. J., 2, 188.

Girard, K. F., and Murray, E. G. D. (1951). Amer. J. med. Sci., 221, 343.

Jessen, O. (1958). Ugeskr. Laoeg., 120, 1701.

Lane, W. F., Watling, J., and Marshall, J. (1959). Monthly Bull. Publ. Hlth Lab. Ser., 18, 127.

Ödegaard, B., Grelland, R., and Henriksen, S. D. (1952). Acta med. scand., 142, 231.

Seeliger, H. P. R. (1958). Listeriose, 2nd ed. Barth, Leipzig.

Seeliger, H. P. R. (1958). Listeriose, 2nd ed. Barth, Leipzig. Atlanta, Georgia.

Joint WHO/FAO Export Committee on Zoonoses. Second Report. (1959). Wld. Hlth Org. and Techn. Rep. Ser. pp. 49, 58, and 63.

Wedemeyer, F. W., and Seeliger, H. P. R. (1959). Arch. Kinderheilk., $160,25$.

Winn, J. F., Cherry, W. B., and King, E. O. (1958). Ann. N.Y. Acad. Sci., 70, 624. 